\title{
Publicidade do Sabão em Pó Omo em 1957 e 2007: um modelo de produção de sentido
}

\author{
Marina Aparecida Espinosa Negri*
}

Resumo: Este artigo faz um paralelo entre as linhas de comunicação empregadas na Publicidade do sabão em pó Omo em duas faixas temporais específicas: os anos de 1957 e 2007, para através dele, elaborar o percurso gerativo de sentido de cada uma das emissões. Considerando-se os contextos em que foram produzidas ambas as campanhas, o desdobramento do estudo permite a verificação não apenas teórica dos componentes da Análise do Discurso nos conceitos adotados, conforme descritos no livro Elementos de Análise do Discurso, de José Luiz Fiorin; mas também prática, em relação a certas particularidades sociais dessas épocas, e o conseqüente alinhamento do manifesto publicitário a cada uma delas.

Palavras-Chave: Publicidade; fala; a produção de sentido; paradoxo

\begin{abstract}
This article draws a parallel between the lines of communication used in advertising soap powder Omo into two age-specific time: the years 1957 and 2007, for through it, draw the production of meaning of each of the emissions. Considering the contexts in which both campaigns were produced, the development of the study wants to check not only the theoretical components of discourse analysis, on the concepts adopted, as described in the book Elements of Discourse Analysis, by Jose Luiz Fiorin; but also the practice ones, in relation to certain social characteristics of these times, and the consequent alignment of advertising manifest with each one of them.
\end{abstract}

Keywords: Advertising; speech; the production of meaning; paradox.

No Brasil, Omo é um produto líder inconteste de vendas no seu segmento desde que foi lançado, em meados da década de 50, resguardando intacta sua imagem de eficiência e confiabilidade frente ao público-alvo, e tendo seu nome transformado em um quase sinônimo de sabão em pó.

Seu intuito norteador é, através da identificação e recomposição dos elementos da Análise do Discurso na peça selecionada, demonstrar a necessidade de alinhamento

\footnotetext{
* Doutoranda em Artes pelo Instituto de Artes da Universidade Estadual de Campinas.
} 
da mensagem publicitária a contextos diferenciados, considerando-se fatores de natureza objetiva, como o enquadramento das marcas em estratégias mercadológicas; e de natureza subjetiva, como a condição humana e a mutabilidade dos padrões comportamentais, sociais, familiares e éticos, ao longo do tempo.

A partir da observação do modelo de produção de sentido adotado na criação do anúncio de 1957, aqui se procura estabelecer a constituição de seu percurso gerativo de sentido, à luz dos conceitos declinados por Algirdas Julien Greimas (1973), que expandiram a tradicional noção de Semântica Estrutural, circunscrita à palavra.

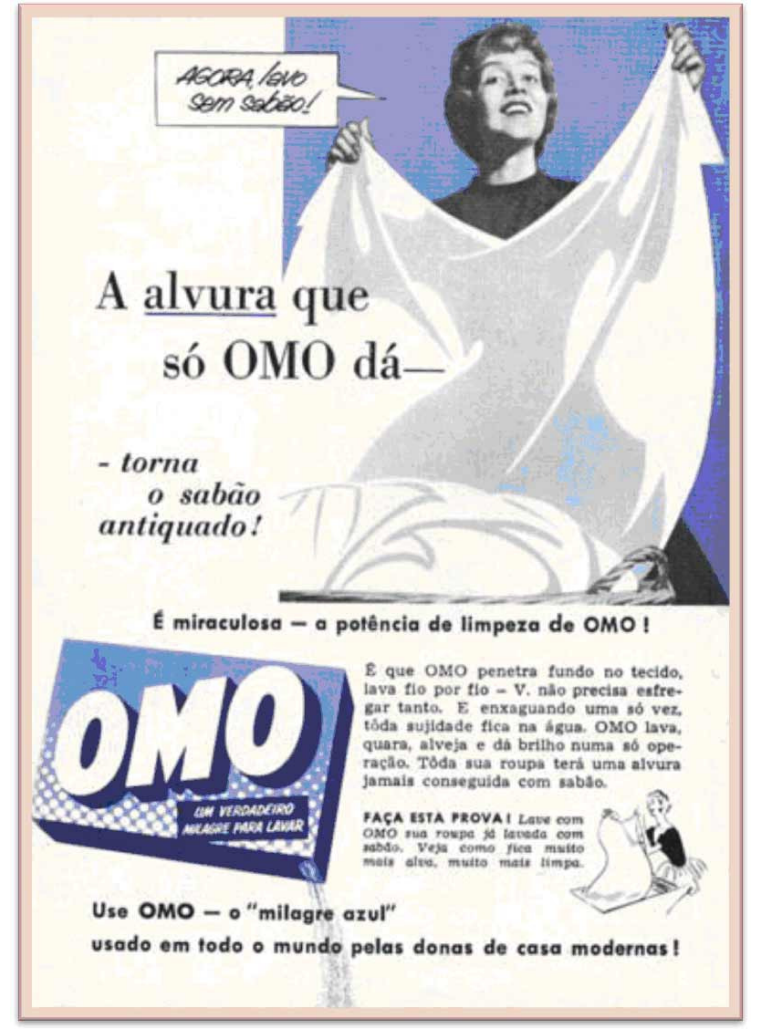

Figura 1:

Anúncio do sabão em pó Omo | 1957: a brancura / alvura das roupas aparece como carro-chefe da Publicidade. Disponível em: http://www.mundodasmarcas.blogspot.co m/2006/05/omo-lava-mais-branco.html

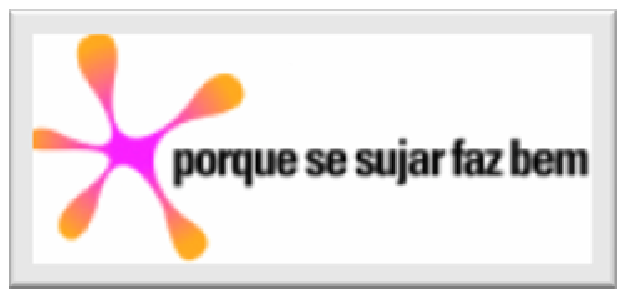

Figura 2:

Slogan de Omo | 2007: confiante e controverso. Disponível em:

http://www.mundodasmarcas.blogspot.com/2006/ 05/omo-lava-mais-branco.html

Tendo fracassado o projeto da Semântica Estrutural, conforme originalmente firmado, grande parte dos lingüistas ampliou seu olhar, passando a se preocupar com unidades maiores do que a palavra. Ducrot, por exemplo, debruçou-se sobre os 
implícitos do discurso, e começou a desenvolver o que chamou de Semântica Lingüística; outros, como Greimas, direcionaram-se aos problemas do discurso, (FIORIN, 1989, p.12) e é precisamente sobre essa inclinação que se desenvolve este trabalho, uma vez que, por meio dela, é possível detectar nuanças, matizes e ruídos eventuais na emissão e na captação de mensagens, campo fértil de análise, no caso do manifesto publicitário.

Assim, será considerada a catalogação de Greimas, para quem uma Semântica deve ser:

a) Gerativa, ou seja, deve estabelecer modelos que apreendam os níveis de invariância crescente do sentido de tal forma que se perceba que diferentes elementos do nível de superfície podem significar a mesma coisa num nível mais profundo.

b) Sintagmática, isto é, deve explicar não as unidades lexicais que entram na feitura das frases, mas a produção e a interpretação do discurso.

c) Geral, ou seja, deve ter como postulado a unicidade de sentido, que pode ser manifestado por diferentes planos de expressão. (FIORIN, 1989, p. 13).

$\mathrm{Na}$ abertura da explanação, é realizado o seqüenciamento do percurso gerativo de sentido do anúncio de 1957, instaurado com a inclusão desse objeto nas duas plataformas de significação previstas para o entendimento de qualquer mensagem: a racional, denominada Estrutura Aparente; e a emocional, nomeada Estrutura Profunda, a seguir dispostas de forma esquematizada.

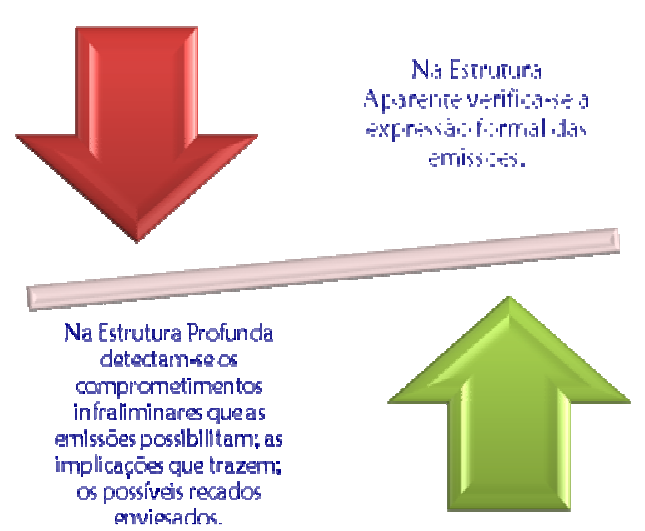

O adensamento do estudo de ambas encontra boa fundamentação na obra de Umberto Eco, A estrutura ausente (1972, p. 156) aqui atuando como suporte teórico. 
Na Estrutura Aparente, (Plano de Expressão) a mensagem é analisada por suas características formadoras visíveis e objetivas, ou seja - pela Denotação. Na Estrutura Profunda, (Plano de Conteúdo) detectam-se os comprometimentos infraliminares que a emissão possibilita; as implicações que traz; os possíveis recados enviesados - a Conotação.

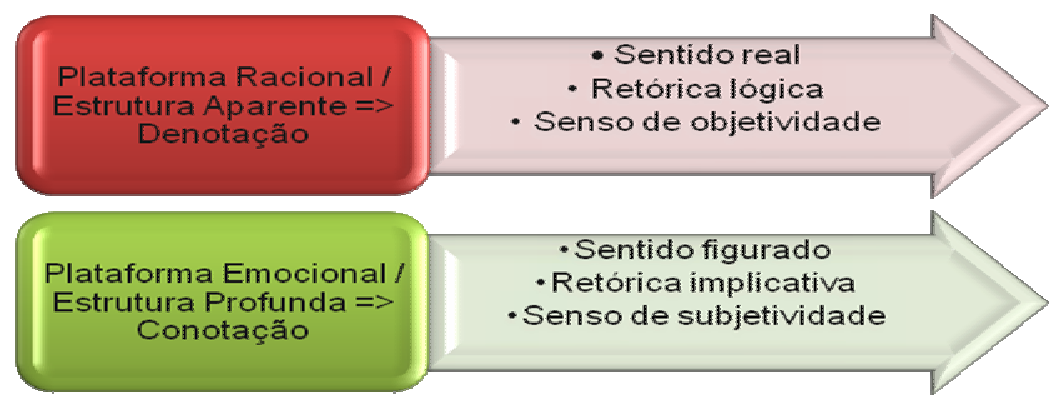

Aplicadas no anúncio de Omo / 1957, tais Estruturas estabelecem-se da seguinte forma:

$\Rightarrow \quad$ Estrutura Aparente - Denotação, com:

- A descrição técnica dos elementos verbais da peça

- A descrição técnica dos elementos visuais da peça

$\Rightarrow \quad$ Estrutura Profunda - Conotação, com:

- O enquadramento do anúncio nos três níveis do percurso gerativo de sentido: o Fundamental, o Narrativo e o Discursivo

No Nível Fundamental, são exploradas as Relações de Contrariedade e as Relações de Contraditoriedade - variantes de uma Relação de Oposição Semântica entre dois elementos em pressuposição recíproca. São expostos também, dois importantes conceitos: o de Euforia e o de Disforia, que, em tese, demonstram a pertinência de qualificações atribuídas a dado objeto no contexto em que se insere. Essa atribuição de valores positivos e negativos a um objeto, no entanto, não é absoluta ou irrefutável, mas volátil, e diretamente vinculada às características de cada contexto, e não ao sistema axiológico $^{1}$ do leitor. $\mathrm{O}$ conhecimento dessas noções é determinante para que se possa presumir com alguma segurança tanto as intenções da mensagem do anúncio de Omo de 1957, como as da campanha de 2007. 
No Nível Narrativo, são discriminadas as quatro fases de ação pelas quais passará o sujeito de um enunciado narrativo: a da manipulação, a da competência, a da performance, e a da sanção. Postas nessa ordem $=>$ Enredo Linear, ou em ordem variável => Enredo Alinear, elas formam o escopo de uma Narração propriamente dita, modalidade discursiva em que se enquadra o anúncio de 57.

No último estágio, o Nível Discursivo, diferenciam-se quatro conceitos importantes para a formação de uma Narração: Texto e Discurso; Figuras e Temas, a fim de que se obtenha uma percepção mais concreta dos elementos estruturantes das Narrações, e não se os encare como sinônimos uns dos outros.

Nas Associações Finais, o raciocínio converge para uma insólita bifurcação de direções, resultante da análise empreendida: o apelo do anúncio de Omo em 1957 é colocado em analogia com a mensagem da campanha do produto em 2007, e nesse momento, percebe-se que os enunciados entram numa espécie de rota de colisão. A confrontação expressiva na propositura das duas mensagens é referendada por quatro paradoxos incisivos o suficiente para, a um só tempo:

$\Rightarrow$ Desconstruir a lógica da Publicidade de 1957, se transmitida nos dias de hoje.

$\Rightarrow$ Inviabilizar a divulgação de Omo, como definida em 2007, ao público receptor de 1957.

Aparentemente, as duas linhas de comunicação adotadas são ideias tão antagônicas, que parecem não corroborar a imagem de um mesmo produto. Por outro lado, é possível reconhecer que elas têm sua própria lógica funcional, e fazem todo o sentido, se consideradas as faixas temporais em que foram concebidas, e as circunstâncias sócio-culturais dos públicos-alvo. Com isso posto, almeja-se deixar demonstrada a obrigatoriedade da pronta adequação do discurso publicitário a diferentes épocas, ambientes e destinatários, ainda que certas mensagens de uma mesma marca pareçam contradizer-se, desmentir-se, ou até negar-se a si próprias, com o passar do tempo.

O procedimento, embora a princípio possa parecer disparatado, e mesmo paradoxal, não configura, entretanto, um deslocamento inconsequente, ou mero artifício de oportunismo. Na verdade, a comunicação publicitária precisa e busca evocar sentido 
para atingir seu maior objetivo - a persuasão dos destinatários, trabalho que envolve questões de razoável complexidade, algumas delas neste Artigo trazidas à tona.

A fim de que se produza uma antevisão em nível macroscópico do contexto em que transitam atualmente a anunciante Unilever e a marca Omo, abre-se um panorama sintetizado, com a apresentação de alguns dados referenciais corporativos.

A marca no mundo:

$\Rightarrow \quad$ A marca Omo comercializa seus produtos em mais de 28 países ao redor do mundo, tendo no Brasil um de seus principais mercados e com forte presença na Europa, América Latina e Ásia.

$\Rightarrow \quad$ É uma das mais rentáveis e fortes da Unilever, faturando anualmente mais de US\$ 2.5 bilhões.

$\Rightarrow \quad$ A marca Omo responde por cerca de 50\% do mercado brasileiro de sabão em pó, estando presente em cerca de 32 milhões de domicílios no país, que consomem mais de 365 milhões de embalagens.

$\Rightarrow \quad$ Um milhão de embalagens de Omo por dia: esta é a média de produção do detergente em pó líder no Brasil. ${ }^{2}$

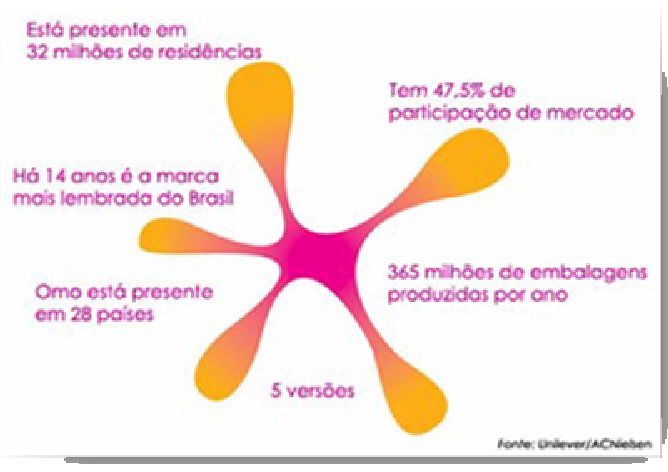

Figura 3:

Referencial numérico datado da marca Omo | 2007.

Disponível em: http://www. mundodasmarcas.blogs pot.com/2006/05/omo-lava-maisbranco.html

Além do apoio bibliográfico dirigido, esta escritura registra e, de certo modo, dialoga com algumas contribuições de pesquisadores brasileiros, autores de trabalhos fundamentados em similar perspectiva, cuja difusão trouxe luz a conceitos intrincados.

\footnotetext{
${ }^{2}$ Dados e informações extraídos das seguintes fontes: website oficial (reproduzido em vários idiomas): http://www.omo.com.br; Unilever; AC Nielsen; revistas (Fortune, Forbes, Newsweek, BusinessWeek e IstoÉ Dinheiro); websites especializados em Marketing e Branding (Brand Channel e Interbrand); Wikipedia (informações devidamente checadas); e websites financeiros (Google Finance, Yahoo Finance e Hoovers).
} 
Entre as mais próximas desta análise, mencionam-se as publicações: Subsídios semióticos para a análise temática do texto publicitário ${ }^{3}$, de Valdirene Pereira da Conceição; A narratividade do texto publicitário ${ }^{4}$, de Roseane Nicolau; ...Valores agenciados nas narrativas da publicidade televisiva de Nova Schin ${ }^{5}$, de Juliana Zanini Salbego; Publicidade e narrativa, de Luís Nogueira ${ }^{6}$.

\section{Estrutura aparente do anúncio de Omo - 1957: elementos verbais e elementos visuais}

Sob o ponto-de-vista estético, a peça obedeceu ao padrão clássico de anúncio página simples de revista, e apresentou todos os elementos verbo-visuais componentes da mensagem publicitária de perfil ortodoxo, dirigida à mídia impressa, a saber: Título, Texto, Imagem e Slogan. Ela recebeu também um tratamento visual gráfico com aplicação de duas cores e está conformada em formato A4, ou seja, é própria para inserção em uma página.

- No plano visual, ela é formada a partir de uma hibridização de recursos gráficos, que exibe na imagem uma mescla de:

$\Rightarrow$ Fotografia aplicada ao produto e à dona-de-casa que o utiliza.

$\Rightarrow$ Ilustração a nanquim aplicada para a exemplificação de uma dona-de-casa em processo de lavagem manual de roupas num tanque.

- No plano verbal, há o registro dos três elementos componentes da Redação Publicitária:

$\Rightarrow$ Um Título misto, composto por uma frase de natureza discursiva apodítica, ${ }^{7}$ ou a que exalta uma verdade absoluta: A alvura que só Omo dá torna o sabão

\footnotetext{
${ }^{3}$ Apresentado no XV Seminário Nacional de Bibliotecas Universitárias / SBNU - SP, s/d. Disponível em: http://wwww.sbu.unicamp.br.

4 Publicado on line na Revista Eletrônica Temática, em julho / 2005. Disponível em: http://www.insite.pro.br

5 Publicado on line na UniRevista, Vol. I - $\mathrm{N}^{\mathrm{o}}$ 03, em julho / 2006. Disponível em: http://www.unirevista.unisinos.br

${ }^{6}$ Disponível em: http://www.labcom.ubi.pt

${ }^{7}$ Raciocínio Apodítico, ou verdade inquestionável, representa uma das três gradações de Raciocínios Discursivos codificadas pela Retórica, e analisadas por Umberto Eco em A obra aberta (1972, p. 279); posteriormente, por vários outros autores, como Margarida Andrade \& João Bosco Medeiros, no livro Curso de Língua Portuguesa (1997, p. 76-79); e Adilson Citelli, em Linguagem e Persuasão (2000, pp. 18-20). Os demais tipos de Raciocínios Discursivos categorizados são: o Dialético, que busca quebrar a inflexibilidade característica do Apodítico, objetivando a persuasão racional do interlocutor; e o Retórico, que atua na esfera emocional do receptor, não tentando apenas convencê-lo sobre algo, mas procurando também influenciar seu sistema psicológico. Os três são empregados indistintamente em Redação Publicitária.
} 
antiquado! + um Subtítulo igualmente apodítico: É miraculosa a potência de limpeza de Omo! + um baloon com a fala insólita da consumidora, em discurso direto: Agora, lavo sem sabão!

$\Rightarrow$ Um Texto em Estrutura Discursiva Descritiva com incursões de fala dirigida à consumidora, e recorrência a verbos no tempo imperativo, sugerindo uma conversa amistosa entre o anunciante e a dona-de-casa, potencial usuária do produto.

$\Rightarrow$ Um Slogan de cunho hiperbólico: Use Omo, o milagre azul - usado em todo o mundo pelas donas-de-casa modernas! - formulação frasal que resgata toda a proposição verbal da peça, construída mediante o uso da Figura de Linguagem Semântica Hipérbole; e das Funções de Linguagem Emotiva, Referencial e Conativa, em combinação simultânea.

Deve-se levar em conta o fato de que na década de 50, o sabão em pó significava uma verdadeira revolução no segmento limpeza doméstica, entrando no mercado como alternativa superior aos sabões em pedra. Tratava-se então, de um produto que não era conhecido, nem chamado de sabão, mas sim, de pó azul ou pó mágico, por isso, tais expressões, de uso corrente à época, estão inscritas no anúncio ora analisado.

\section{Noções elementares sobre percurso gerativo de sentido}

A começar por algumas revisões essenciais, colaboradoras para o entendimento da Semântica de categoria Gerativa, destacam-se algumas colocações de Fiorin, todas direcionadas às bases que a compõem. Desenvolver determinados elementos dessa Semântica Gerativa possibilita a interpretação de textos quaisquer, em nível profundo.

Assim, parece relevante a apreensão inicial tanto das definições informais e disseminadas de Semântica e Percurso gerativo de sentido; como das funções da Semântica e da Sintaxe no plano da Gramática, e no plano da Teoria do Discurso, dentro dos quais a ambas são atribuídos significados diferentes.

Semântica define-se, normalmente, como 'estudo do significado' ou 'teoria da significação'. [...] Um campo semântico é um conjunto de unidades lexicais associadas por uma determinada estrutura subjacente. (FIORIN, 1989 - p. 11,12).

Na gramática, a sintaxe faz par com a semântica. Enquanto esta estuda a estrutura do vocábulo, aquela dedica-se ao exame das regras que presidem as relações entre os vocábulos [...] Numa teoria do discurso, a sintaxe contrapõese à semântica. [...] 
A distinção entre sintaxe e semântica não decorre do fato de que uma seja significativa e a outra não, mas de que a sintaxe é mais autônoma do que a semântica, na medida em que uma mesma relação sintática pode receber uma variedade imensa de investimentos semânticos. (Idem, p. 17).

O estudo de Fiorin esclarece que, com o tempo, a definição de Semântica, de acordo como apresentada acima, tornou-se insatisfatória, perdeu força, deixando lacunas enquanto conceituação teórica. $\mathrm{O}$ autor aborda a preocupação de vários lingüistas que, por constatarem o caráter reducionista do entendimento de Semântica, voltaram-se para a análise de unidades de significação maiores do que a palavra, passando a se interessar pelos problemas do discurso. Procede de Algirdas Julien Greimas, um dos mais influentes, a expressão Semântica Gerativa, variante que se inclina para a interpretação aprofundada de textos, mediante um percurso gerativo de sentido, desdobrado em três patamares nomeados, respectivamente:

- O Nível Profundo ou Fundamental

- O Nível Narrativo

- O Nível Discursivo

"O percurso gerativo de sentido é uma sucessão de patamares, cada um dos quais, suscetível de receber uma descrição adequada, que mostra como se produz e se interpreta o sentido, num processo que vai do mais simples ao mais complexo. [...] (FIORIN, 1989, p. 17)”.

O presente trabalho fundamenta-se nesses ordenamentos internos do discurso, para fazer uma análise comparativa detalhada das linhas de comunicação adotadas na Publicidade do sabão em pó Omo em 1957 e 2007, e identificar, assim, as manobras persuasivas das campanhas veiculadas nos dois momentos. O objetivo principal dessa analogia temporal a ser aberta passo a passo, é, por meio de cada etapa componente do percurso gerativo de sentido, revelar os comprometimentos subliminares das mensagens emitidas em cada um dos casos. É também, demonstrar a necessidade de adaptação do discurso publicitário ao espectro sócio-temporal em que se insere, ainda que suas resoluções criativas pareçam surpreendentes, ou mesmo contraditórias, se comparadas cronologicamente. 
As duas temáticas regentes das campanhas de Omo em 1957 e 2007 foram escolhidas como corpus deste estudo exatamente por isso. Encaradas sob o arcabouço da Análise do Discurso, e pelas características antagônicas das sociedades que compunham as faixas temporais mencionadas, elas parecem negar-se entre si.

Postos em confronto, os dois conceitos de campanha, à primeira vista sugerem descompromisso com a lógica formal, e também com a imagem corporativa da marca. No entanto, sob olhar mais treinado e calcado em subsídios teóricos, revelam-se decisões criativas conscientes e totalmente respaldadas nas proposições dos contextos sociais em que foram veiculadas.

O desenvolvimento seguinte mostra o enquadramento do anúncio de 1957 nas três etapas componentes do percurso gerativo de sentido, captadas no bojo da peça, com vistas à remontagem do modelo de produção de sentido supostamente adotado quando de sua criação.

\section{Estrutura profunda do anúncio de Omo - 1957: três níveis do percurso gerativo de sentido}

\subsection{Nível fundamental}

É este o patamar que abriga as categorias semânticas localizadas na base de construção de um texto. Para existir, uma categoria semântica fundamenta-se basicamente numa diferença, ou oposição entre dois termos, os quais, para poderem ser apreendidos conjuntamente, deverão ter algo em comum. Sobre esse traço comum, estabelece-se a diferença, ou oposição - o estado de coisas que causa uma tensão dialética. A oposição semântica é percebida em nível concreto, e depois, em nível abstrato, numa sucessão de patamares, que vão do mais simples ao mais complexo.

Não se contrapõem, por exemplo, os termos /naturalidade/ a /fidelidade/, uma vez que eles nada têm em comum, ou seja, não pertencem a um mesmo campo semântico, e não são capazes de provocar tensão dialética entre si. Contudo, é possível verificar-se uma clara oposição semântica entre /naturalidade/ e /artificialidade/, pois ambos os elementos situam-se no domínio dos campos: /aparência física/, /comportamento/, /alimentação/ e outros, dependendo da circunscrição em que sejam utilizados. Além disso, eles estão em pressuposição recíproca; têm algo em comum; e em conjunção precipitam um estado de tensão mútua, condições essenciais para o surgimento de uma Relação de Oposição. 
Aplicando-se esses mesmos fundamentos ao anúncio de Omo aqui analisado, é possível verificar-se a presença da oposição semântica em nível fundamental entre duas situações, que se faz representar de várias maneiras, e por condições distintas, dentre as quais, assinalamos em primeiro lugar as de: /sujeira/ x /limpeza/.

- $\quad$ É inequivocamente desejável, em praticamente qualquer ambiente, a limpeza no lugar da sujeira, porém, no contexto de costumes em que o produto foi lançado, a sujeira tinha valor negativo ainda maior, e funcionava como elemento disfórico. A limpeza, por sua vez, tinha valor positivo, e atuava, portanto, como elemento eufórico. A principal oposição semântica em nível concreto da mensagem emitida nessa peça insurge-se aqui, portanto.

Em 1957, era comum a associação de roupas limpas com roupas brancas. O processo de industrialização era ainda incipiente no Brasil e, conseqüentemente, a variedade de roupas em relação a padrões, cores e estilos mantinha-se restrita. Costureiras e alfaiates faziam as roupas da população, e não existia a produção seriada de vestimentas na escala feérica que se conhece hoje. A profusão de cores e estamparias era também limitada, sendo o branco, a cor preferencial em todas as classes sociais. Se uma peça de roupa não estivesse de fato branca, seria vista como encardida ou suja, e, na melhor das hipóteses, mal lavada, o que significaria um cartão de visitas nefasto a alguém que assim se trajasse publicamente. Atingiria, também, a reboque, e no plano infraliminar, a reputação da dona-de-casa responsável por tal lavagem de roupa, posicionando-a como relapsa em relação aos serviços domésticos. O lançamento de Omo consolida essa oposição inicial e figura no anúncio como uma resposta / solução moderna para garantir a condição de limpeza das roupas, uma evolução naquele momento.

- Ainda no nível concreto de percepção da produção de sentido, tem-se uma segunda oposição semântica, agora instaurada entre duas determinadas ações: /lavar roupas com sabão/ x /lavar roupas com Omo/, ou entre: /trabalho pesado/ x /trabalho leve/.

Lavar, esfregar, deixar de molho, enxaguar, quarar e estender roupas eram tarefas árduas, porém bastante usuais às donas-de-casa dos anos 50. Esse ciclo desenvolvia-se com o uso do sabão em barra, algumas vezes complementado por alvejantes e pedras de azul anil. Trabalho difícil e extenuante, compensado com o advento dos sabões em pó, que, além de deixarem as roupas mais brancas, 
tiravam a dona-de-casa desse serviço pesado. Possivelmente, seja esse o nível mais concreto de percepção da produção de sentido do anúncio analisado, e pode também ter sido esse, o seu mote principal de Criação Publicitária. No anúncio, Omo aparece como alternativa inovadora, moderna e altamente eficiente para a lavagem de roupas, situando-se como um coadjuvante da dona-de-casa, capaz de tirá-la das funções cansativas do cotidiano doméstico.

- Já, em nível abstrato de percepção de produção de sentido, é possível diagnosticar uma terceira oposição semântica, mais ampla, sugerida entre as condições de: /ser uma dona-de-casa moderna/ x /ser uma dona-de-casa antiquada/; ou entre /presente/ x /passado/.

À época em que o anúncio foi veiculado, roupas limpas, além de uma óbvia denotação de higiene, sugeriam ser sinônimo consensual de dedicação da mulher ao casamento, sendo esse comportamento quase sempre associado à devoção ao marido e aos filhos, e às obrigações de uma mulher de família naquele momento. Usar um produto novo que trouxesse benefícios ao lar poderia repercutir como uma maneira de ela se considerar moderna e preocupada em proporcionar coisas novas ao seu núcleo familiar. Poderia igualmente representar uma forma de ela ser encarada como uma mulher de seu tempo, alinhada com o progresso e com as inovações por ele trazidas.

Uma vez realçadas tais plataformas de oposição entre situações, intui-se que, para produzir sentido em 1957, a Publicidade de Omo teve seu conceito firmado principalmente no ineditismo desse novo produto. A idéia-mestra era apresentar Omo não como um simples sabão, mas sim, um pó mágico com surpreendente poder na lavagem das roupas, uma invenção maravilhosa, comparada a um milagre. Seus benefícios, então novidade para o momento, extrapolavam a esfera do plano concreto e atingiam o plano abstrato do entendimento humano, com grande força persuasiva. Omo era um agente promotor de limpeza, e senha para o ingresso na modernidade.

Para que se possa fazer uma correlação informal entre abordagens criativas, e se alcance melhor visão tanto dos produtos, como do cenário social em que a campanha de Omo foi concebida, segue em destaque um anúncio do sabão em pó Rinso, seu mais forte concorrente nas décadas de 50 e 60. 


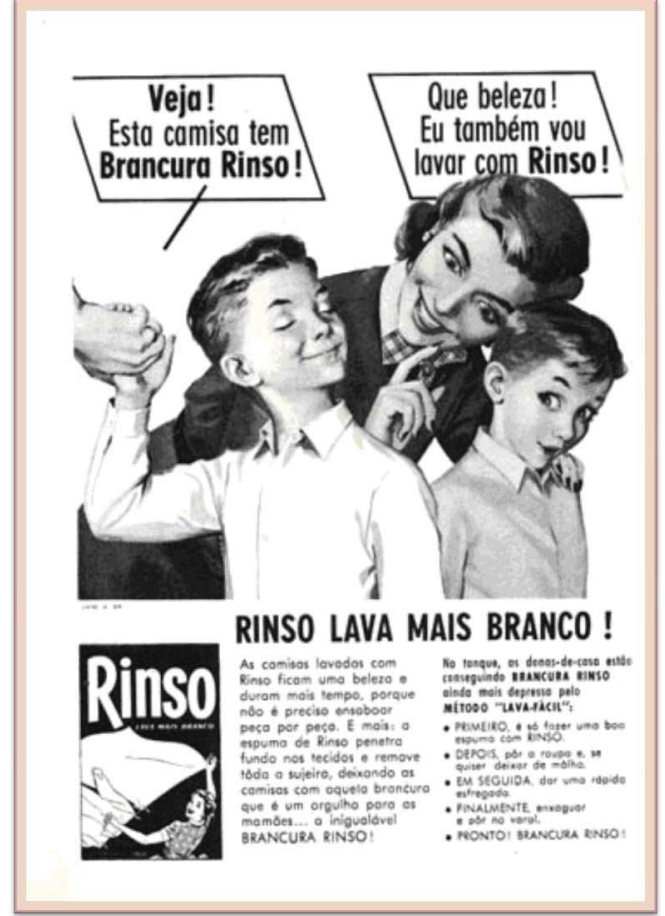

Figura 4:

Anúncio do Sabão em Pó Rinso | 1958 criado em moldes semelhantes aos do anúncio de Omo: a brancura das roupas confirma-se como carro-chefe da Publicidade.

Disponível em:

http://www.mundodasmarcas.blogspot.com/20 06/05/omo-lava-mais-branco.html

No exemplo selecionado, o popular Rinso é anunciado com recorrência aos seguintes estratagemas criativos:
$\Rightarrow$ Resolução verbal firmada em uma explanação longa, explicativa e sedutora, complementada por aparato visual baseado em ilustração a nanquim, e inserção escrita de diálogos em forma de balloons, um padrão bastante em moda, na década de 50 .
$\Rightarrow \mathrm{Na}$ mensagem verbo-visual, tanto no anúncio de Rinso, como no de Omo, identifica-se semelhante evocação à brancura das roupas, sublinhando sua condição de objeto-valor à época.
$\Rightarrow$ A palavra 'brancura' ${ }^{8}$ foi diagramada em caixa alta no primeiro baloon.
$\Rightarrow$ Na peça há também a associação do branco a limpeza, modernidade e dedicação à família e ao lar, reiterada na fala admirada da mulher, expressa no segundo baloon.

Trata-se de uma variação branda do apelo emitido na Publicidade de Omo.

\subsubsection{Relações de contrariedade e relações de contraditoriedade}

\footnotetext{
${ }^{8}$ Numa demonstração pontual do poder persuasivo da Publicidade, bem como de sua capacidade de aproximar as marcas do público, inserindo-as como participantes do cotidiano social, a expressão 'Brancura Rinso' ganhou repercussão notável, e se tornou um jargão na década de 50, estendendo-se até meados da década de 70. Ela atuou como reforço adjetivo coloquial em situações nas quais a menção à alvura, brancura ou mesmo à pureza de algo se fizesse necessária.
} 
O prosseguimento do estudo direciona a abordagem ainda para o entendimento sobre oposição semântica entre dois termos, e, de acordo com a versão de Fiorin, é preciso que se faça um importante adensamento nesse sentido.

Sabe-se que termos opostos de uma dada categoria semântica mantêm entre si uma conseqüente relação de contrariedade, facilmente observável. Em outras palavras: são chamados contrários os termos que se encontram em pressuposição recíproca imediata. A esse tipo de oposição, primária, mais simples e evidente, nomeia-se: Relação de Contrariedade.

Conduzindo o enfoque ao exemplo recém fornecido, tem-se que, para ganhar sentido, o termo /naturalidade/ pressupõe instantaneamente o termo /artificialidade/; e vice-versa, sendo que essa oposição direta configura a chamada Relação de Contrariedade entre eles.

Todavia, elaborar apenas a Relação de Contrariedade não conclui nem explica totalmente uma oposição semântica entre dois termos, havendo necessidade de se desdobrá-la mais profundamente para esgotar suas proporções. Assim, se for efetuada uma operação secundária e mais sofisticada de negação de cada um dos contrários vistos na Relação de Contrariedade, ocorrerão agora dois contraditórios, originando uma segunda variante de oposição semântica: a Relação de Contraditoriedade.

Ilustrada por meio dos dois termos já utilizados como referência, em uma Relação de Contraditoriedade, as oposições previstas seriam as seguintes: /naturalidade/ implica /não-naturalidade/; /artificialidade/ implica /não-artificialidade/, lembrando que os dois contraditórios (/não-naturalidade/ e /não-artificialidade/) são, por sua vez, contrários entre si. A fim de diferenciá-los dos outros contrários ocorridos no primeiro tipo de Relação, (/naturalidade/ x /artificialidade/), eles serão denominados subcontrários.

A distinção cabal entre as Relações de Contrariedade e as Relações de Contraditoriedade reside no fato de que:

$\Rightarrow$ Nas Relações de Contrariedade, os termos em oposição (/naturalidade/ x /artificialidade/) possuem cada qual um conteúdo específico.

$\Rightarrow$ Nas Relações de Contraditoriedade, os termos em oposição (/nãonaturalidade/ x /não-artificialidade/) são definidos pela presença e pela ausência de determinado traço. 
A partir do domínio dessas noções, é possível localizar os dois tipos de relação na mensagem do anúncio de Omo, para então, se verificar em qual delas o conceito criativo da campanha de 1957 foi provavelmente baseado.

A grande oposição presente na Publicidade do sabão em pó Omo / 1957 encontra-se no binômio /modernidade/ x /antiguidade/, termos opostos de uma mesma categoria semântica, que mantêm entre si uma Relação de Contrariedade. O termo /modernidade/ pressupõe o termo /antiguidade/ tanto para obter sentido, como para impulsionar uma tensão dialética, e vice-versa. Em outras palavras, o contrário de /modernidade/ é /antiguidade/.

Uma operação de negação a cada um desses contrários firmaria uma Relação de Contraditoriedade na mensagem do anúncio, e resultaria em dois contraditórios: /nãomodernidade/, que é o exato contraditório de /modernidade/; e /não antiguidade/, que é o contraditório de /antiguidade/. Esses dois contraditórios /não modernidade/ e /não antiguidade/, contrários entre si, são, em verdade, os chamados subcontrários, como já ressalvado.

Em síntese:

$\Rightarrow$ As Relações de Contrariedade entre /modernidade/ x /antiguidade/ mostram que cada um dos termos dessa maneira confrontados possui certo conteúdo positivo. No caso do anúncio analisado, a /modernidade/ não é a ausência de /antiguidade/, mas sim, "uma marca semântica específica". (FIORIN, 1989 p. 19).

$\Rightarrow$ As Relações de Contraditoriedade entre /modernidade/ e /não modernidade/ e /antiguidade/ e /não antiguidade/ definem-se respectivamente pela presença e pela ausência de um determinado traço. No anúncio, /modernidade/ implica /não antiguidade/, e /antiguidade/ implica /não modernidade/.

Esses sutis (e, de certa maneira, discutíveis) diferenciais permitem depreender que a oposição semântica entre dois termos, subjacente no plano abstrato do anúncio de Omo / 1957, não configurou, propriamente, uma Relação de Contrariedade, na qual um termo teria de imediato pressuposto o outro.

Salvaguardando-se a previsibilidade de alguma margem de erro na interpretação, é mais razoável supor que ela tenha sido baseada em uma Relação de Contraditoriedade, que permeou toda a construção verbo-visual da mensagem. A dedução tem amparo no 
recado final captado no anúncio, levando à conclusão de que: quem lava roupas com sabão (em barra) é /não moderno/, e quem lava roupas com Omo (em pó) é /não antiquado/.

Relação de oposição essa, outorgada pela presença e pela ausência de um determinado traço, marca precípua da Relação de Contraditoriedade.

\subsubsection{Conceito de euforia e conceito de disforia}

A qualificação de um elemento como eufórico (de valor positivo), ou disfórico (de valor negativo), depende do texto no qual se inscreve, e do contexto em que opera.

Durante uma entrevista de avaliação de um candidato para eventual contratação profissional, ser /natural/ pode significar um traço favorável, bem indicado ao pretendente à vaga, comportamento valorizado como positivo $=>$ elemento eufórico nessa situação. Já, comportar-se de modo /artificial/ em tais circunstâncias seria, portanto, um procedimento considerado desfavorável, contra-indicado, de valor negativo $=>$ elemento disfórico, no caso.

Nenhum elemento pode ser catalogado como eufórico ou disfórico de forma isolada, à parte do texto em que foi inscrito. Sua compreensão e seu status estarão diretamente implicados no sistema de valores de cada texto. Uma determinada marca de comportamento, a /submissão/, por exemplo, pode ser avaliada como elemento eufórico em um texto, e como disfórico em outro com igual pertinência, já que esse juízo de valor depende do ambiente do texto em que ela estiver enquadrada.

Cada um dos elementos da categoria semântica de base de um texto recebe a qualificação semântica /euforia/ x /disforia/. O termo ao qual foi aplicada a marca /disforia/ é visto como um valor negativo. (...) /Euforia/ e /disforia/ não são valores determinados pelo sistema axiológico do leitor, mas estão inscritos no texto. (FIORIN, 1989, p. 20).

No anúncio da década de 50, já foram citados os termos /sujeira/ e /limpeza/, formando uma oposição semântica de nível concreto, e atuando respectivamente como disfórico e eufórico no contexto em que foram veiculados. Entretanto, para alargamento dos conceitos de Euforia e Disforia, há de se assinalar mais um par semântico inscrito 
na peça, e já analisado sob outros aspectos: trata-se dos elementos /modernidade/ e /antiguidade/.

O primeiro, /modernidade/, é conotado como positivo naquele contexto, e tem, por conta disso, valor eufórico, diretamente explicitado e captado nos planos verbal e visual.

- No plano verbal da peça, com as expressões:

Agora, lavo sem sabão!

A alvura que só Omo dá torna o sabão antiquado!

Use Omo, o milagre azul - usado em todo o mundo pelas donas-de-casa modernas!

- No plano visual, em que se nota:

Uma sobrevalorização da dona-de-casa usuária de Omo, conotada pela sua disposição gráfica, bem no foco central da página, fotografada em tamanho grande. Ela tem aspecto jovem, e está sorridente e bem disposta em meio ao trabalho com as roupas.

O segundo termo, /antiguidade/, tem alta carga negativa, e, no anúncio está indiretamente expresso pelas imagens e pelo texto completo, atuando como elemento disfórico no conjunto da mensagem.

Pode-se perceber a desvalorização da dona-de-casa que usa sabão em pedra, que foi minimizada na ilustração a nanquim, (forma de ilustração mais antiga do que a fotografia), e relegada ao segundo plano, na ala lateral do quadrante ótico do anúncio. Ela é mais velha e parece cansada com o serviço braçal.

Os elementos valorizados, positivos $\Rightarrow$ eufóricos do anúncio são mais notadamente: /limpeza/ e /modernidade/. Os desvalorizados, negativos => disfóricos seriam: /sujeira/ e /antiguidade/.

\subsection{Nível narrativo}

Em definição informal, compreende-se Narração como o ato de se contar uma história, na qual seus elementos formadores apresentam-se na trama em dada disposição; defrontam um conflito que os faz passar por uma ou mais mudanças, em qualquer grau; sofrem uma quebra na estabilidade; e são conduzidos, por fim, a uma 
nova situação, em estado necessariamente diferente do inicial. Trata-se, portanto, de um texto dinâmico, por natureza, no qual ações se encadeiam e caminham para um desfecho.

Já, Narratividade, de acordo com Platão \& Fiorin (1996 - p. 229), seria “a própria transformação de situações [...]”, ocorrência esperada em textos narrativos. É precisamente a presença da Narratividade que formaliza uma Narração; é seu filamento genético.

\footnotetext{
A primeira objeção que se poderia fazer, quando se diz que um dos níveis do percurso gerativo é o narrativo, é que nem todos os textos são narrativos. $\mathrm{Na}$ realidade, é preciso fazer uma distinção entre narratividade e narração. Aquela é componente de todos os textos, enquanto esta concerne a uma determinada classe de textos. A narratividade é uma transformação situada entre dois estados sucessivos e diferentes. Isso significa que ocorre uma narrativa mínima, quando se tem um estado inicial, uma transformação e um estado final. (FIORIN, 1989, p. 21).
}

A assimilação de tais distinções no plano teórico permite a aferição de sua aplicabilidade no exemplo aqui analisado.

Um olhar fatídico poderia diagnosticar que a estrutura discursiva formal do texto do anúncio de Omo / 1957 não é narrativa, como se a aceita em tese, mas sim, descritiva, modalidade discursiva de caráter estático, que se presta a arrolar traços de um objeto para compô-lo no imaginário de quem lê. Do ponto-de-vista técnico, não há de fato uma história sendo contada na peça, e sim, uma definição (em tom grandiloquente) das potencialidades / traços do sabão em pó Omo, o que colocaria esse anúncio no molde da Descrição, e não no da Narração.

Porém, sob reparo menos ortodoxo, consegue-se vislumbrar um discreto viés narrativo na peça, se forem pontuados o antes \& depois na rotina da dona-de-casa que utiliza Omo, como a expressão da narratividade. A adoção do produto no cotidiano doméstico teria proporcionado uma mudança para melhor na vida dessa dona-de-casa, emprestando à mensagem a marca distintiva da estrutura narrativa, por excelência, - a transformação de situações.

Mediante essa perspectiva, o anúncio de Omo / 1957 pode ser encaixado no molde da Narração. 
Direcionando o enfoque agora para o plano sintático, é importante diferenciar os dois tipos de enunciados básicos, presumíveis em um texto narrativo:

Na sintaxe narrativa, há dois tipos de enunciados elementares:

a) Enunciados de estado: são os que estabelecem uma relação de junção (disjunção ou conjunção) entre um sujeito e um objeto.

b) Enunciados de fazer: são os que mostram as transformações, os que correspondem à passagem de um enunciado de estado a outro. (FIORIN, 1989, p. 21).

No anúncio de Omo, a mensagem conforma-se em um enunciado de estado (relação de conjunção), a qual se faz representar pela parceria / conjunção entre: donade-casa (sujeito) $\Leftrightarrow$ Omo (objeto), produzindo resultados compensadores.

Existe também, um enunciado de fazer (mostrando passagens e transformações de uma situação para outra), quando se afirma que: o trabalho com a lavagem de roupas outrora pesado => ficará bem mais leve com Omo; roupas não se lavam mais com sabão $=>$ e sim, com Omo; donas-de-casa antiquadas usam sabão em pedra $=>$ mulheres modernas usam Omo.

Mesmo perpassando todas essas sutilezas de fundo, ainda é preciso salientar uma premissa maior, que não subestima a complexidade dos textos, e os sublinha como organismos não simplificados.

Os textos não são narrativas mínimas. Ao contrário, são narrativas complexas, em que uma série de enunciados de fazer e de ser (de estado) estão organizados hierarquicamente. Uma narrativa complexa estrutura-se numa seqüência canônica, que compreende quatro fases: a manipulação, a competência, a performance e a sanção. [...] (FIORIN, 1989, p. 22).

Visto enquanto 'narrativa complexa', depreende-se que no anúncio de 1957, existem as quatro fases componentes de sua sequência canônica: a da manipulação, a da competência, a da performance e a da sanção, respectivamente, as quais ocorrem em etapas paulatinas, e possuem características individualizantes.

- $\quad$ A primeira delas é a da manipulação do sujeito, no caso, pela sedução. (No anúncio, ela se consolida com a inclinação da mensagem instando a donade-casa a fazer uso do produto, já que as donas-de-casa modernas do mundo inteiro já o utilizam). 
- A fase da competência é a que mostra o sujeito que fará a transformação central da narrativa. (No anúncio, o sujeito é a dona-de-casa, que usando Omo, será dotada de uma habilitação especial, ou um poder fazer).

- A fase da performance é o momento em que ocorre a mudança de um estado para outro: a narratividade. (No anúncio, há a passagem da dona-de-casa que decide usar Omo, da situação de desempenho antiquado para a de desempenho moderno).

- $\quad \mathrm{Na}$ fase da sanção, ocorre a constatação de que a performance (ou o desempenho) realizou-se, e o reconhecimento ou premiação do sujeito se efetiva. (No anúncio, pressupõe-se que o prêmio para essa dona-de-casa que passou a usar Omo é o reconhecimento de seus familiares por sua dedicação ao lar, e pelo bom cumprimento das obrigações domésticas com aquilo que existe de mais revolucionário no mercado).

\subsection{Nível discursivo}

Para melhor fruição deste breve tópico, é oportuna a adoção de duas iniciativas prévias. A primeira é que se leve em consideração uma discriminação pontual entre os níveis Narrativo e Discursivo, bem marcada por Fiorin, a saber:

No nível narrativo, temos formas abstratas como um sujeito entrar em conjunção com a riqueza. No nível discursivo, as formas abstratas do nível narrativo são revestidas de termos que lhe dão concretude. (...) O nível discursivo produz variações de conteúdos narrativos invariantes. (FIORIN, 1989, p. 29).

A segunda é que, diante desse conhecimento, sejam relembradas algumas prédefinições de conceitos e seus diferenciais de base, não raro confundidos entre si, ou considerados sinônimos uns dos outros, equivocadamente.

- Discurso => Conteúdo (Aquilo que é dito de fato)

- Texto $=>$ Expressão (A forma de se dizer)

- Figuras $=>$ Elementos pertencentes ao Plano Concreto do entendimento humano (Objetos)

- Temas $=>$ Elementos pertencentes ao Plano Abstrato do entendimento humano (Idéias) 
O Nível Discursivo refere-se à forma de se contar uma história, isto é, de se expressar uma Narrativa. O que caracteriza uma fábula, um drama, uma novela, uma piada, (todas essas, manifestações eminentemente narrativas), e os distingue de outra manifestação equivalente é justamente o discurso, a capa narrativa, ou a figuratividade que cada uma dessas histórias apresenta.

No caso de o produto Omo ser o protagonista das ações de um enredo / trama narrativa publicitária, seria viável dramatizar-se o conflito da busca pela brancura de roupas (objeto-valor) de muitas maneiras, como as sugeridas:

- Fazer a comparação direta entre o uso de práticas ultrapassadas, como esfregar as peças com pedras de sabão, pedras de anil, enxaguá-las, deixá-las quarando ao sol etc, e a de usar Omo, alternativa que anularia todas as fases dessa operação braçal, e produziria um rápido e excelente resultado.

- Mostrar Omo como uma extensão das práticas modernas, enfatizando que uma mulher pode utilizar-se de muitos artifícios para ser vista como atualizada, inclusive usar Omo na lavagem de roupas da sua família.

- Recorrer aos costumes então em voga, e demonstrar que, para ser bem vistas, as pessoas da década de 50 precisavam exibir roupas alvas, tradução mais aceita da condição de asseio; de cuidados com a aparência; de se pertencer a uma boa família, por assim dizer, sendo Omo o caminho-resposta para se obter essa condição.

Todas seriam formas propícias para reger o enredo / trama narrativa publicitária.

\section{Associações finais}

Com ancoragem na fundamentação teórica dos Elementos da Análise do Discurso, proposta pelo Prof. Fiorin, é possível, nestas associações finais, fazer o registro de importantes paradoxos (ou oposições) detectados mediante a analogia das campanhas publicitárias do sabão em pó Omo de 1957 e de 2007.

São vários contrastes, dentre os quais há de se salientar os quatro mais eloquentes, que atestam a necessidade de adequação do manifesto publicitário a imposições não apenas mercadológicas, mas principalmente às idiossincrasias sóciotemporais, a fim de que lhe sejam conferidos o mérito da verossimilhança e o poder de convencimento. 
$\Rightarrow$ Existe uma macro-oposição / Antítese de fundo entre as emissões publicitárias de Omo de 1957 e 2007.

Enquanto a primeira abordagem valorizava a brancura das roupas, (elemento eufórico em 1957), a recente linha de comunicação da campanha de Omo, referendada pela assinatura de marca: Porque se sujar faz bem, comemora a sujeira, (elemento eufórico em 2007), mostrada como facilitadora do processo de aprendizado e crescimento, com uma conotação libertária. Se antigamente a limpeza era um valor unívoco e inquestionável, hoje, ela não possui o mesmo status. O slogan de Omo agora exalta o seu oposto, isto é: o que na década de 50 era valor eufórico, no século XXI é valor disfórico. Ele é tão vinculado a essa contundente transformação de valores, que exibe em sua formulação verbal a supressão do nome do produto, expressando confiança de que a população receptora (público-alvo) reconhecerá nela o sujeito enunciador, Omo, em oculto.

$\Rightarrow$ Um segundo paradoxo pode ser encontrado no bojo das idéias conflitantes que deram corpo / leit motiv ${ }^{9}$ às duas mensagens.

Como já exposto, em 1957, o objeto-valor principal era a dona-de-casa manter alvas (limpas, brancas) as roupas de toda a sua família por conta das razões já explicitadas nesta análise. Ou seja, a limpeza (traduzida por brancura) era o grande objeto-valor nesse momento. Havia então, uma sobrevalorização das instituições casamento e família, projetadas nos benefícios do produto Omo, que, por ser capaz de conferir brancura às roupas, reforçava essa valorização, tornando-a o carro-chefe de sua Publicidade. Hoje, o objeto-valor principal para a consumidora (que não se configura necessariamente como uma senhora casada, e ainda menos como dedicada exclusivamente ao lar), tem outra versão, e se expressa por meio de sua atitude de adequação às imposições dos novos tempos. Ao permitir, concordar e valorizar o fato de seus filhos se sujarem à vontade em suas brincadeiras, ela reitera a mensagem de que se sujar faz bem, atribuindo-lhe valor eufórico. Essa nova consumidora encarna o modelo contemporâneo de mãe presente e participativa, com atitudes de encorajamento à

\footnotetext{
9 Leit motiv, no jargão da Publicidade, significa 'motivo principal' ou 'razão determinante' para originar o conceito de uma campanha.
} 
liberdade, e incentivo ao afloramento de talentos intrínsecos das crianças e adolescentes.

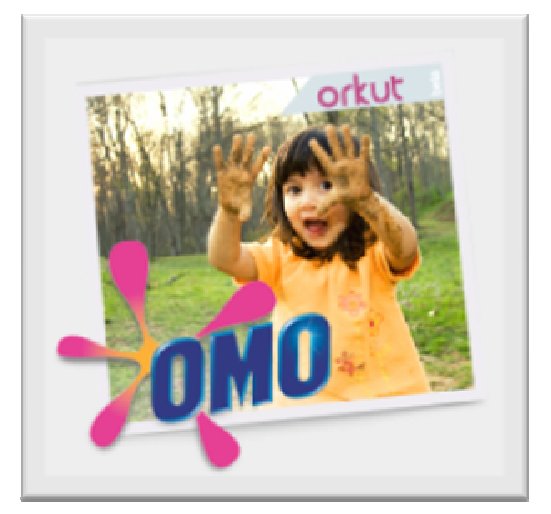

Figura 5:

Anúncio do Sabão em Pó Omo I 2007: a sujeira nas roupas aparece como carro-chefe da Publicidade.

Disponível em: http: //www.omo.com.br

$\Rightarrow \quad \mathrm{O}$ terceiro paradoxo refere-se à brancura das roupas, qualidade exaltada na década de 50, e no século XXI minimizada, talvez desprezível.

Hoje, a alvura das roupas não chega a ser um objetivo, (no jargão teórico - um objeto-valor), mais se assemelhando a um problema a ser evitado no cotidiano doméstico. Na mesma medida, em relação à Publicidade, a posição do branco, ou da brancura também decaiu. Por já não significar mais sinal de apreço e cuidado com a família, é incapaz de sustentar por si só a argumentação das atuais campanhas de sabões em pó, precisando aliar-se às outras cores para produzir sentido, como ilustra a cena abaixo.

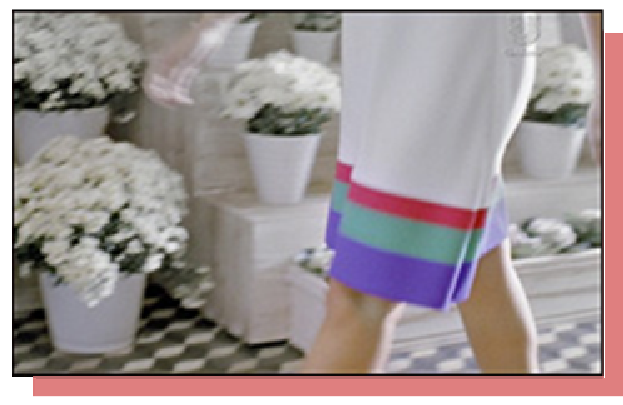

Figura 6:

Fotograma de comercial (30") veiculado em 2009 do sabão em pó Brilhante, concorrente de Omo: hoje, a brancura das roupas, isoladamente, não é mais um objeto-valor; mas sim, a brancura junto com a vivacidade das outras cores.

Disponível em:

http://www.meioemensagem.com.br I Newsletter 04/04/2009. 
A nova ênfase ganhou notoriedade a partir de 2000, quando, não por acaso, ocorreu uma guinada importante em relação à tecla principal a ser batida na comunicação da marca Omo, mostrada em parte na tabela ao lado.

Do trivial slogan: Você pode contar com ele sempre, a concepção da mensagem publicitária de Omo tomaria outro rumo, vindo a exemplificar situações em que a ação de se sujar colaboraria decisivamente com o aprendizado, em diversos tipos de atividades.

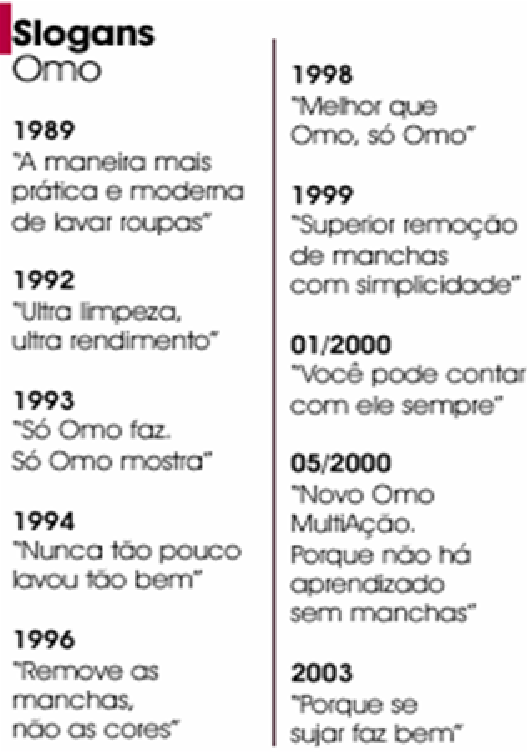

Ela então passaria a pregar verdades quase irrefutáveis, como: Novo Omo Multi Ação. Porque não há aprendizado sem manchas. O conceito agrada, marca presença, acaba evoluindo, e, em 2003, corporifica o slogan aqui estudado: Porque se sujar faz bem, contraponto literal da mensagem de Omo, em 1957.

$\Rightarrow \quad$ Um último e irônico paradoxo, de natureza ainda mais abstrata, subjaz na Estrutura Profunda da recente Publicidade de Omo, e pode ser captado quando se atenta para o período político em que a assinatura da marca conquistou seu ápice de memorização.

A veiculação da campanha coincide (ou colide?...) perigosamente com um dos mais escabrosos episódios protagonizados por parlamentares brasileiros - o Escândalo do Mensalão do PT - o qual, embora tenha contado com provas incontestáveis dos abusos praticados, não conseguiu ensejar a punição de nenhum dos envolvidos. A imprevista associação entre o malsinado evento político e o slogan: Porque se sujar faz. bem comprometeu e alterou uma vez mais a valoração dos conceitos de Euforia e Disforia dessa mensagem, pois, com o advento desse novo contexto, a expressão 'se sujar faz bem', até então eufórica, ganhou valor disfórico. Vista sob esse prisma, a inesperada antítese arranhou a imagem da marca, e não poderia ter sido enunciada em pior hora, uma vez que sugere estimular a corrupção, por conta da impunidade reinante no país.

\section{REFERÊNCIAS BIBLIOGRÁFICAS}

ECO, Umberto. A estrutura ausente. São Paulo: Ed. Perspectiva, 1972. 
A obra aberta. Coleção Debates $-\mathrm{n}^{0}$ 4. São Paulo: Ed. Perspectiva, $8^{\mathrm{a}}$ edição, 2001.

FIORIN, José Luiz. Elementos de Análise do Discurso - Série: Repensando a Língua Portuguesa. São Paulo: Ed. Contexto/Universidade de São Paulo, 1989.

GREIMAS, Algirdas Julien. Semântica estrutural. São Paulo: Ed. Cultrix,1973.

PLATÃO, Francisco José Savióli \& FIORIN, José Luiz. Lições de texto: Leitura e Redação. São Paulo: Ed. Ática, 1996. 